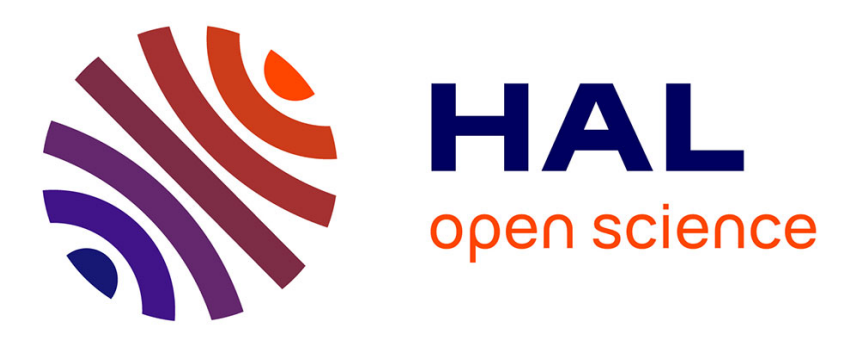

\title{
Functional diversity in root and above-ground traits in a fertile grassland shows a detrimental effect on productivity
}

Pierre Chanteloup, Anne Bonis

\section{- To cite this version:}

Pierre Chanteloup, Anne Bonis. Functional diversity in root and above-ground traits in a fertile grassland shows a detrimental effect on productivity. Basic and Applied Ecology, 2013, 14 (3), pp.208216. 10.1016/j.baae.2013.01.002 . hal-00853778

\section{HAL Id: hal-00853778 https://hal.science/hal-00853778}

Submitted on 25 Nov 2020

HAL is a multi-disciplinary open access archive for the deposit and dissemination of scientific research documents, whether they are published or not. The documents may come from teaching and research institutions in France or abroad, or from public or private research centers.
L'archive ouverte pluridisciplinaire HAL, est destinée au dépôt et à la diffusion de documents scientifiques de niveau recherche, publiés ou non, émanant des établissements d'enseignement et de recherche français ou étrangers, des laboratoires publics ou privés. 


\section{Basic and Applied Ecology}

www.elsevier.com/locate/baae

\title{
Functional diversity in root and above-ground traits in a fertile grassland shows a detrimental effect on productivity
}

\author{
Pierre Chanteloup, Anne Bonis* \\ UMR-CNRS 6553 ECOBIO-OSU de Rennes, Université de Rennes 1, Campus de Beaulieu, 35042 Rennes Cedex, France
}

Received 5 April 2012; accepted 2 January 2013

\begin{abstract}
Plant community functional structure may drive ecosystem functions in relation with (i) the trait values characterizing dominant species, according to the "biomass ratio hypothesis" proposed by Grime, and (ii) thanks to trait dissimilarity among species, according to the "diversity hypothesis" proposed by Tilman. Both propositions have already yielded support but their relative importance and how they impact biomass production in field situations is still not well known. This study therefore tested (i) whether or not there was a close relationship between biomass production and the community-weighted mean trait values $(\mathrm{CWM})$, as expected from the "biomass ratio hypothesis", and (ii) the impact of the functional diversity $\left(\mathrm{FD}_{\mathrm{Q}}\right)$ on biomass production, which is expected to be positive according to the "diversity-hypothesis". The study considered a range of plant assemblages occurring in a wet grassland and five above-ground and four below-ground plant traits were measured to characterize their functional structure. The effects of species diversity, soil water content, soil nitrogen availability and grazing intensity on biomass production were also determined.

We showed that biomass production was not related either to species richness and diversity or to any of the resource and disturbance parameters considered. Conversely, the functional structure was found to explain up to $55 \%$ of the variability of the biomass production. The results obtained clearly supported the "biomass-ratio hypothesis". Functional diversity was mainly found to negatively impact biomass production with only poor support to the "diversity hypothesis". We suggest that such a dilution effect of increasing $\mathrm{FD}_{\mathrm{Q}}$ on community primary production may be typical of fertile habitats.

In order to significantly improve our understanding of the relationship between functional diversity and ecosystem processes, further studies should consider plant assemblages that have been shaped over the long term and habitats across a wide range of productivity.
\end{abstract}

\section{Zusammenfassung}

Ökosystemfunktionen werden durch die funktionale Struktur von Pflanzengemeinschaften beeinflusst, und zwar in Bezug auf (i) die Merkmalswerte der dominanten Arten nach der "Biomassen-Verhältnis-Theorie" von Grime und (ii) aufgrund der Verschiedenheit der Merkmale zwischen den Arten nach der "Diversitäts-Hypothese" von Tilman. Beide Hypothesen haben bereits Unterstützung erfahren, aber es ist bisher noch nicht bekannt, wie ihre relative Bedeutung ist und welchen Einfluss sie auf die Biomassenproduktion unter Freilandbedingungen haben. Diese Studie untersuchte deshalb, (i) ob es eine enge Beziehung zwischen der Biomassenproduktion und den gewichteten, durchschnittlichen Merkmalswerten der Lebensgemeinschaften (CWM) gibt, wie es aufgrund der "Biomassen-Verhältnis-Theorie" erwartet werden kann, und (ii) den Einfluss der funktionalen Diversität $\left(\mathrm{FD}_{\mathrm{Q}}\right)$ auf die Biomassenproduktion, der nach der "Diversitäts-Hypothese" positiv sein sollte. Diese

\footnotetext{
*Corresponding author. Tel.: +33 223235134; fax: +33 223235067.

E-mail address: anne.bonis@univ-rennes1.fr (A. Bonis).
} 
Studie berücksichtigte eine Anzahl von Pflanzengemeinschaften, die in feuchten Grünländern vorkommen, und es wurden fünf oberirdische und vier unterirdische Pflanzenmerkmale gemessen, um die funktionale Struktur zu charakterisieren. Die Auswirkungen der Artendiversität, des Bodenwassergehaltes, der Verfügbarkeit von Bodenstickstoff und die Beweidungsintensität auf die Biomassenproduktion wurden ebenfalls gemessen. Wir zeigten, dass die Biomassenproduktion nicht mit dem Artenreichtum und der Diversität oder irgendeinem der Ressourcen- oder Störungsparameter zusammenhing. Im Gegensatz dazu konnte die funktionale Struktur bis zu 55\% in der Variation der Biomassenproduktion erklären. Die gewonnenen Ergebnisse stützen eindeutig die "Biomassen-Verhältnis-Theorie". Wir fanden heraus, dass die funktionale Diversität die Biomassenproduktion vor allem negativ beeinflusste und die "Diversitäts-Hypothese" daher kaum unterstützt wurde. Solch ein Verdünnungseffekt der zunehmenden $\mathrm{FD}_{\mathrm{Q}}$ auf die primäre Produktion der Gemeinschaft könnte typisch für fruchtbare Habitate sein. Wir schlagen daher vor, dass Untersuchungen, die dazu dienen sollen, unser Verständnis über die Beziehung zwischen der funktionalen Diversität und den Ökosystem-Prozessen signifikant zu verbessern, sowohl die Pflanzenzusammensetzung, die sich langfristig ausgebildet hat, als auch Habitate über eine große Bandbreite der Produktivität berücksichtigt.

() 2013 Gesellschaft für Ökologie. Published by Elsevier GmbH. All rights reserved.

Keywords: Functional traits; Community-weighted mean; Rao's functional diversity index; Biomass production; NPP; Biodiversity; Biomass ratio hypothesis; Diversity hypothesis

\section{Introduction}

The study of the relationship between plant community diversity and ecosystem functioning emerged as a central issue in ecology in the mid-1990s (Schulze \& Mooney 1993; Tilman et al. 1997). It became particularly important with the increased demand for knowledge about the impact of global change by citizens and decision-makers (Millenium Ecosystem Assessment 2005). Dedicated research has generally shown that biodiversity has a positive effect on ecosystem processes, particularly on primary production (Hooper et al. 2005). However, these results were mainly obtained by using experimental assemblages (e.g., Tilman et al. 1997; Hector et al. 1999), a method that has been criticized because of the artificiality of the communities created (e.g., Grime 1997; Huston et al. 2000; Lepš 2004).

Beyond a species richness effect on the productivity of plant communities, Tilman et al. (1997) and Hector et al. (1999) showed that functional group richness (i.e., the number of groups based on physiological and/or morphological differences) plays a prominent role in biomass production. The study of functional traits (sensu Violle et al. 2007) was shown to provide a more general understanding of the relationships between biodiversity and ecosystem properties (Díaz \& Cabido 2001; Hooper et al. 2005; McGill, Enquist, Weiher, \& Westoby 2006). In particular, the identity, abundance and range of species traits, i.e., the functional structure, were found to be the main drivers of ecosystem processes (Díaz et al. 2004; Lavorel \& Garnier 2002).

Two main hypotheses have been proposed regarding the effect of functional structure on ecosystem processes. The "biomass ratio hypothesis" (Grime 1998) proposes that the effect of traits on ecosystem properties depends on the values of the species traits, in proportion to their relative abundance. According to this hypothesis, the functioning of an ecosystem primarily depends on the values of the functional traits for the dominant species (Grime 1998). This hypothesis was globally confirmed by studies considering ecosystem processes such as productivity (Garnier et al. 2004), the rate of litter decomposition (Garnier et al. 2004), and the nitrification rate (Laughlin 2011). Conversely, the "diversity hypothesis" derived from Tilman's (1997) seminal work proposes that the diversity of organisms and the diversity of their functional traits within a community affects ecosystem processes. A high level of functional diversity may enable complementary resource use among species together with a reduction of negative biotic interactions, thereby improving the functioning of the system (Hooper 1998; Loreau 2000; Díaz \& Cabido 2001). The "diversity hypothesis" is primarily supported by studies manipulating the number of functional groups (e.g., Tilman et al. 1997), while tests taking functional diversity indices into account are still rare (however, see Jiang, Zhang, \& Wang 2007; Mokany, Ash, \& Roxburgh 2008; Schumacher $\&$ Roscher 2009) and lead to mixed results. Jiang et al. (2007) showed that the functional diversity (FD) of artificial communities has a strong positive effect on productivity, whereas Mokany et al. (2008) reported predominantly negative relationships in grasslands.

Mokany et al. (2008) suggested that functional diversity and the trait values of the dominant species most likely influence ecosystem processes together and that the "biomass ratio hypothesis" and the "diversity hypothesis" are not mutually exclusive.

It then becomes a matter of knowing which of these mechanisms has a dominating influence. This work addresses this question by considering biomass production patterns in a wet grazed coastal grassland. The study was carried out on 10 grassland plots sufficiently stable over the years (Marion, Bonis, \& Bouzillé 2010; Dumont et al. 2012) to be shaped by assembly rules. The effect of soil resources, grazing intensity, species richness and functional structure on primary production were considered in both simple regression and multiple regression models. Functional structure was characterized by (i) the community-weighted mean trait values (CWM, Garnier et al. 2004) and (ii) Rao's functional diversity index $\left(\mathrm{FD}_{\mathrm{Q}}\right.$, Lepš, de Bello, Lavorel, \& Berman 2006) 
considering five above-ground and four belowground traits characterizing resource strategies. For a given community, the CWM specifies the weighted mean of a given functional trait and $\mathrm{FD}_{\mathrm{Q}}$ quantifies functional diversity through the dispersion of the trait values (Ricotta \& Moretti 2011). Relationships between functional structure and production were investigated for each trait, as advised by Lepš et al. (2006). Following Díaz, Lavorel, de Bello, et al. (2007), we also searched for the best multiple regression model using a stepwise procedure.

We then investigated (i) if CWM trait values predominantly drive biomass production, as expected from the "biomass ratio hypothesis" and which traits are possibly involved, and (ii) whether species diversity and functional diversity positively affects biomass production, as expected from the "diversity hypothesis".

\section{Methods}

\section{Study site}

This study was conducted on a grazed wet grassland situated in the Marais Poitevin on the French Atlantic coast $\left(46^{\circ} 28^{\prime} \mathrm{N} ; 1^{\circ} 13^{\prime} \mathrm{W}\right)$. The climate is a mild Atlantic type and the soil is characterized by a clayey texture and a markedly hydromorphic character (Amiaud, Bouzillé, Tournade, \& Bonis 1998). This grassland is characterized by a topographical gradient with a maximum amplitude of $70 \mathrm{~cm}$, with three plant communities dominated by grasses and sedges spread along: a mesophilous community on the upper flats, a hygrophilous community on the depressions, and a mesohygrophylous community on the intermediate slopes (Marion et al. 2010). The grassland is extensively grazed by cattle and horses from April to December every year. Its vegetation and management are representative of other commonly owned meadows in the Marais Poitevin (Amiaud et al. 1998). This grassland is productive (Dumont et al. 2012), with a peak biomass in May-June varying from 200 to $900 \mathrm{~g} \mathrm{~m}^{-2}$ depending on the plant assemblage.

\section{Harvest and measurements}

We selected 10 plots $(4 \mathrm{~m} \times 3 \mathrm{~m})$ within a 7-ha grassland area: four plots representing the mesophilous community and six plots representing the meso-hygrophilous community. Plots were selected in order to sample large contrasts regarding species composition and functional structure. Standing biomass was harvested at the beginning of the growing season (March 17th-18th 2010) and at the stand biomass peak (May 26th-28th 2010) with three randomly located $20 \mathrm{~cm} \times 20 \mathrm{~cm}$ samples per plot, protected from grazers. Plant biomass was sorted by species and dried $\left(65^{\circ} \mathrm{C}\right.$ for $48 \mathrm{~h}$ ) in order to obtain the dry mass proportion of the species and their respective peak standing biomass (see Appendix A:
Table 1 for vegetation data). The Net Primary Productivity (NPP) was calculated for each plot following Garnier et al. (2004) and was found to be strongly and linearly related to the peak standing crop $\left(r^{2}=0.86, P<0.001\right)$. Thereafter, the peak standing biomass was used as proxy for plant biomass production.

Species composition and biomass, species richness, Simpson's diversity index (Magurran 1988) and the proportion of perennials were calculated for each sample in May. Together, the soil water content $(\%)$ of the upper soil layer $(0-8 \mathrm{~cm})$ was determined in May for each sample by weighing the fresh and oven-dried soil $\left(105^{\circ} \mathrm{C}\right.$ until constant weight $)$, and soil electrical conductivity $\left(\mathrm{mS} \mathrm{m}^{-1}\right)$ was measured using a W.E.T. sensor (Delta-T Devices Ltd., Cambridge, UK) in order to estimate soil salinity. The soil water content of the upper soil layer showed a close correlation to the content of soil cores taken to a depth of $80 \mathrm{~cm}\left(r^{2}=0.75, P<0.001\right)$ and may thus be considered as a good proxy of water availability over the whole soil profile. The soil mineral nitrogen net content ( $\mu \mathrm{g} \mathrm{g}^{-1}$ dry soil) was determined for each plot: soil inorganic $\mathrm{N}$ of the $0-10 \mathrm{~cm}$ horizon was extracted using a $\mathrm{KCl}$ solution and ammonium and nitrate contents were measured by spectrophotometry (Rossignol, Bonis, \& Bouzillé 2011a). The grazing intensity exerted on the vegetation surrounding each plot from April to June was determined as the percentage of the available forage consumed relatively to the forage available. It was calculated with the "moveable exclosure method" (McNaughton, Milchunas, \& Frank 1996; see Rossignol, Bonis, \& Bouzillé 2011b).

\section{Trait measurements}

We selected five above-ground traits and four belowground traits in order to take into account as many traits as possible representing the leaf economics spectrum (Wright et al. 2004), plant size axis (Westoby, Falster, Moles, Vesk, \& Wright 2002) as well as below-ground strategy (Roumet, Urcelay, \& Díaz 2006). Results were presented for all traits in order to examine plant resource acquisition and use strategies despite some redundancy between traits has been found for eight of the 36 possible pairwise correlations (see Table 1).

Following Cornelissen, Lavorel, Garnier, Díaz, and Buchmann (2003), five above-ground traits were measured in May 2006 for 22 species, representing at least $90 \%$ of the peak standing biomass in the studied plots (Appendix A: Table 1). Specific leaf area (SLA, leaf area per unit dry mass), leaf dry matter content (LDMC, leaf dry mass per unit fresh mass), plant height at the reproductive stage (Hrep), leaf nitrogen concentration (LNC) and leaf carbon concentration (LCC) were measured for a minimum of 20 individuals per species sampled all over the study site on ungrazed plants selected randomly outside the fenced plots.

Root traits were studied for 17 species grown in monoculture in the experimental garden of the University of Rennes (France), using three replicates per species. These 17 species 
Table 1. Pearson correlation matrix of the nine functional traits considered in this study. Abbreviations: SLA, specific leaf area; LDMC, leaf dry matter content; Hrep, reproductive height; LNC, leaf nitrogen concentration; LCC, leaf carbon concentration; \%FineR, proportion of root length with diameter $<0.1 \mathrm{~mm}$; SRA, specific root area; RTD, root tissue density; $90 \%$ RD, depth at which $90 \%$ of total root biomass is achieved.

\begin{tabular}{|c|c|c|c|c|c|c|c|c|}
\hline & SLA & LDMC & Hrep & LNC & LCC & $\%$ FineR & SRA & RTD \\
\hline LDMC & -0.16 & & & & & & & \\
\hline Hrep & -0.17 & $0.76^{* * *}$ & & & & & & \\
\hline LNC & $0.51^{*}$ & -0.09 & -0.07 & & & & & \\
\hline $\mathrm{LCC}$ & 0.08 & 0.34 & 0.15 & $0.69^{* * *}$ & & & & \\
\hline$\%$ FineR & 0.31 & 0.20 & 0.07 & -0.30 & -0.39 & & & \\
\hline SRA & $0.58^{*}$ & -0.18 & 0.00 & -0.29 & $-0.57^{*}$ & $0.61^{* *}$ & & \\
\hline RTD & $-0.63^{* *}$ & 0.24 & -0.02 & 0.14 & $0.40^{\dagger}$ & -0.02 & $-0.77^{* * *}$ & \\
\hline $90 \% \mathrm{RD}$ & 0.01 & -0.20 & -0.06 & 0.18 & 0.19 & -0.29 & -0.16 & -0.11 \\
\hline
\end{tabular}

${ }^{*} P \leq 0.05$.

${ }^{* * *} P \leq 0.01$.

*** $P \leq 0.001$.

${ }^{\dagger} P \leq 0.10$.

yielded at least $80 \%$ of the peak standing biomass in the studied plots (Appendix A: Table 1). The monocultures were grown in PVC tubes in an experimental design similar to that of Craine, Wedin, Chapin, and Reich (2002). Plantlets were obtained from the field and planted at various densities depending on the species (i.e., 2-6 individuals per container) in order to obtain a high density of individuals in the containers. The containers, $16 \mathrm{~cm}$ in diameter and $70 \mathrm{~cm}$ high, were filled with clay-rich garden soil, which was as close as possible to the soil found in the field while still permitting root extraction. Drainage was ensured by holes made in the end of the tubes and a $2-\mathrm{cm}$ layer of gravel at the bottom of the tubes. The containers were buried and the plant species grown from April to December 2010 with drop-to-drop regular water supply. At harvest, the tubes were cut into $10-\mathrm{cm}$ sections, the roots were separated from the soil and washed before being scanned using a flat-bed scanner with a light transparency unit (Epson Perfection V700 Photo). The WinRhizo root analysis program (Regent Instruments, Québec, Canada) was used to obtain root length, diameter, area and volume. The roots were then dried $\left(65^{\circ} \mathrm{C}\right.$ for $\left.72 \mathrm{~h}\right)$ and dry weighed. These measurements allowed us to calculate the proportion of root length with a diameter $<0.1 \mathrm{~mm}$ (\%Fine roots, Craine et al. 2002), specific root area (SRA, root surface area per unit dry mass, Mokany et al. 2008), root tissue density (RTD, root dry mass per root volume when turgid, Craine et al. 2002) and $90 \%$ rooting depth $(90 \% \mathrm{RD}$, i.e., the depth at which $90 \%$ of the total root biomass is estimated using a logistic dose response curve, Schenk \& Jackson 2002).

\section{Functional structure}

The community-weighted mean trait values for each trait were calculated for every sample $(n=30)$ using species trait values and species relative abundances following Garnier et al. (2004) with:

$\mathrm{CWM}=\sum_{i=1}^{n} p_{i}$ trait $_{i}$

where $n$ is the number of species in the sample, $p_{i}$ is the relative abundance of species $i$, and trait ${ }_{i}$ is the trait value of species $i$.

Rao's functional diversity index was calculated using the Excel-macro developed by Lepš et al. (2006) according to the equation:

$\mathrm{FD}_{\mathrm{Q}}=\sum_{i=1}^{n} \sum_{j=1}^{n} p_{i} p_{j} p_{i j}$

where $n$ is the number of species in the sample, $p_{i}$ is the relative abundance of species $i, p_{j}$ is the relative abundance of species $j$, and $d_{i j}$ describes the functional dissimilarity between species $i$ and $j$. This functional diversity measure can be interpreted as the average dissimilarity of two randomly chosen individuals of the studied sample (Lepš et al. 2006; Ricotta \& Moretti 2011). It was calculated for (i) each trait separately, (ii) all below-ground traits, (iii) all above-ground traits and (iv) all nine traits together.

\section{Statistical analysis}

We used linear mixed-models with plot as a random effect to examine the effect on biomass production by the (i) abiotic factors, (ii) community-weighted trait mean, (iii) functional diversity $\left(\mathrm{FD}_{\mathrm{Q}}\right)$ level and (iv) proportion of perennial species for each sample. Plots were included as a random effect in the models as the 30 samples are nested in 10 plots. As proposed by Díaz, Lavorel, de Bello, et al. (2007), we then estimated the best predictive multiple regression mixed-model for biomass production (i.e., the model explaining the highest proportion 

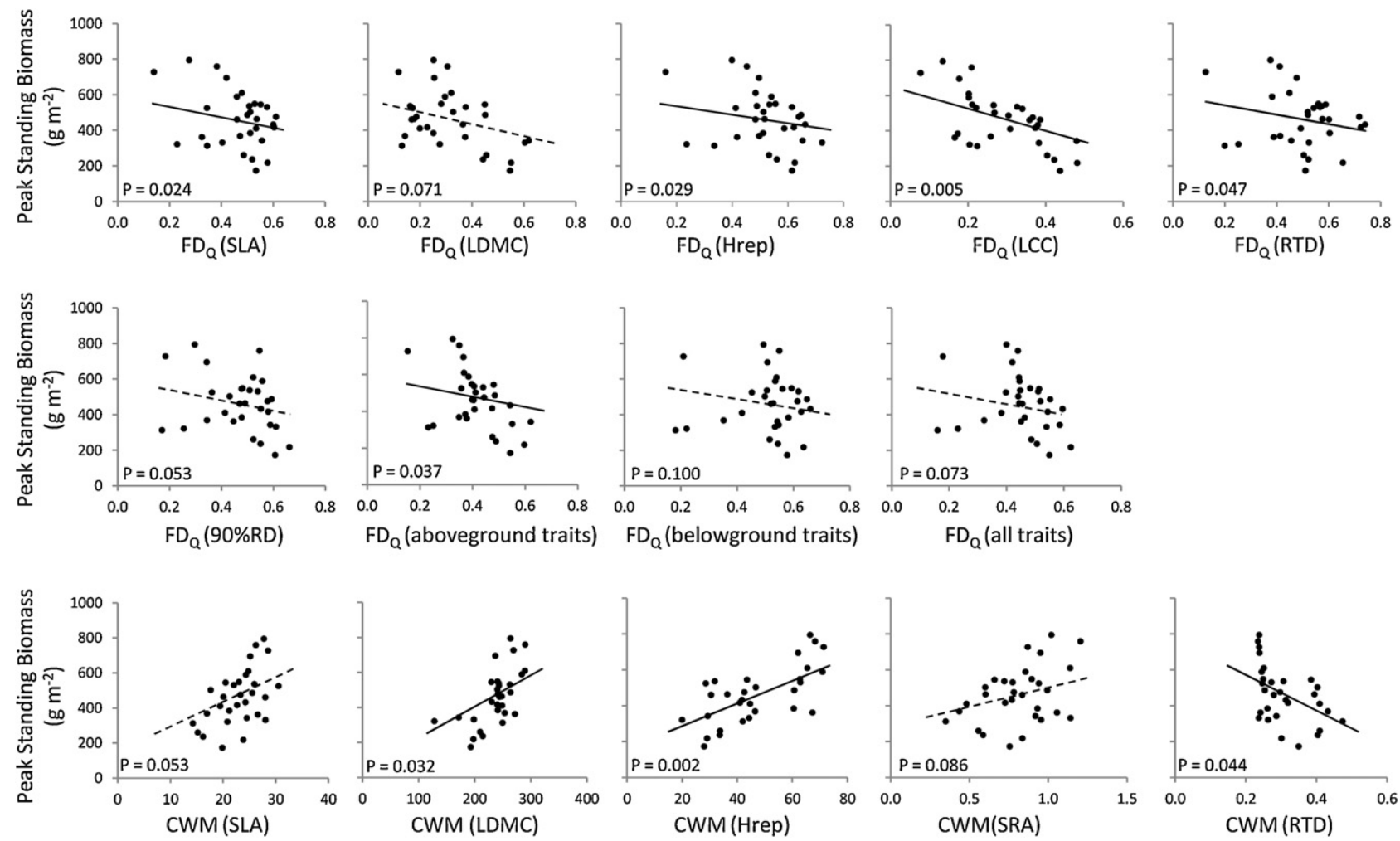

Fig. 1. Peak standing biomass as a function of Rao's index of functional diversity $\left(\mathrm{FD}_{\mathrm{Q}}\right)$ and community weighted mean values $(\mathrm{CWM})$. Full lines indicate linear mixed regressions significant at the 5\% level, dashed lines indicate regressions significant at the $10 \%$ level. Abbreviations as in Table 1.

of variation using the smallest number of explanatory variables). To do so, variables were selected using backward and forward stepwise selection routines along with corrected Akaike Information Criterion (AICc), as recommended by Burnham and Anderson (2002) for small datasets, including only variables where $P=0.05$ or less in the first set of linear mixed-models. As there is currently little consensus on the appropriate way to calculate $r^{2}$ for these type of models, we used the correlation between the observed and predicted values which provides an intuitive measure of the degree to which the best mixed-model explains the variation in biomass production (Wang, Fang, Sanders, White, \& Tang 2009).

All statistical analyses were performed using the R 2.13.0 software ( $R$ Development Core Team, 2011).

\section{Results}

Peak standing crop values varied by four-fold (from $174 \mathrm{~g} \mathrm{~m}^{-2}$ to $795 \mathrm{~g} \mathrm{~m}^{-2}$ ) in the range of samples considered. Species diversity, $\mathrm{FD}_{\mathrm{Q}}$ and $\mathrm{CWM}$ values also showed a large variation in the range of plant assemblages investigated (Appendix A: Table 2). No significant relationship was found between biomass production and soil resources, grazing intensity or soil electrical conductivity (Appendix A: Table 3). Simpson's diversity index and proportion of perennial species relationships with biomass production were marginally significant $(P<0.1)$, no significant relationship was found between species richness and biomass production (Appendix A: Table 3).

Negative relationships between Rao's index of functional diversity (i.e., $\mathrm{FD}_{\mathrm{Q}}$ ) and biomass production were found for all the traits considered (Appendix A: Table 3). These relationships were significant at the $5 \%$ level for four out of the nine studied traits: leaf carbon concentration, specific leaf area, reproductive height and root tissue density. They were significant at the $10 \%$ level for the $90 \%$ rooting depth and leaf dry matter content (Fig. 1). Lastly, multi-trait $\mathrm{FD}_{\mathrm{Q}}$ values were also negatively related to biomass production. The relationships observed between $\mathrm{FD}_{\mathrm{Q}}$ and biomass were similar for the above-ground and below-ground traits (Appendix A: Table 3).

Biomass production was found to be positively related to the community-weighted mean (CWM) trait values for reproductive height, leaf dry matter content, specific leaf area and specific root area and negatively related to CWM for root tissue density (Fig. 1). Conversely, the peak biomass did not show a significant relationship with CWM for leaf nitrogen concentration, leaf carbon concentration, $90 \%$ rooting depth and the proportion of fine roots. Similar results were obtained calculating CWM trait values based on only the two most dominant species (Appendix A: Table 4).

No linear correlation was found between CWM and $\mathrm{FD}_{\mathrm{Q}}$, except for LDMC and 90\%RD (Appendix A: Fig. 1); 
however, these traits showed similar patterns with plant production with regards to other traits.

The best predictive mixed-model combining explanatory variables was found to include $\mathrm{FD}_{\mathrm{Q}}$ and $\mathrm{CWM}$ values, with plot as a random effect. Based on the AICc values, this model was the best over all of the possible models and explained $55 \%$ of the biomass production variance. The fixed effects can be written as follows:

$$
\begin{aligned}
& \text { Biomass production }=479.34-354.78 \mathrm{FD}_{\mathrm{Q}}(\mathrm{SLA}) \\
& +6.41 \mathrm{FD}_{\mathrm{Q}}(\mathrm{Hrep})-132.61 \mathrm{FD}_{\mathrm{Q}}(\mathrm{LCC}) \\
& +161.21 \mathrm{FD}_{\mathrm{Q}}(\mathrm{RTD})+5.19 \mathrm{CWM}(\mathrm{Hrep}) \\
& -463.17 \mathrm{CWM}(\mathrm{RTD})
\end{aligned}
$$

\section{Discussion}

\section{Influence of environmental factors}

Abiotic factors typically explain a significant proportion of the variation of ecosystem processes such as biomass production (Loreau et al. 2001) and in particular, soil nitrogen concentration often appears to be among the main predictors of above-ground biomass (e.g., Díaz, Lavorel, de Bello, et al. 2007; Schumacher \& Roscher 2009). Our results, showing no significant effect of soil mineral nitrogen content or soil water content on biomass production despite clear contrasts among samples, were thus unexpected. In the type of fertile grasslands studied (Dumont et al. 2012), the functional structure indeed appears to have a much greater effect on biomass production than soil water and nitrogen availability.

\section{Influence of species richness}

Contrary to many previous studies (review in Hooper et al. 2005), our study, as well as that of Mouillot, Villéger, SchererLorenzen, \& Mason (2011), showed that biomass production was not significantly related to species richness. This result may be due to the absence of very low species richness in the range of situations investigated. Indeed, the positive effect of species richness on primary production shown previously vanished when the richness was around five species (Hooper et al. 2005) and thus appears restricted to a range of low species richness. Our results support the view that, beyond a minimal richness threshold (e.g., four species in our study as in the study of Mouillot et al. 2011), species richness does not drive significantly plant production.

\section{Influence of the functional structure}

Unlike species richness, functional structure appears to be a significant driver for plant production. The results obtained here showed a significant negative relationship between production and $\mathrm{FD}_{\mathrm{Q}}$ for most of the traits. CWM trait values were also found to be related to production for a majority of the traits.

\section{The CWM - biomass production relationship}

As proposed by the "biomass ratio hypothesis" (Grime 1998), CWM trait values were linked to biomass production for three out of the nine studied traits at the $5 \%$ level of significance (five out of nine at the $10 \%$ level). Therefore, biomass production appeared to be strongly linked to the trait values of the dominant species as shown by Garnier et al. (2004) for above-ground traits and suggested by Roumet et al. (2006) for below-ground traits. Same results were obtained by only considering the two most dominant species (Appendix A: Table 4) and this support the view that the dominant species drive ecosystem processes (e.g., Garnier et al. 2004 for litter decomposition; Laughlin 2011 for nitrification), particularly primary production (Garnier et al. 2004; Mokany et al. 2008; Schumacher \& Roscher 2009; Roscher et al. 2012). This relationship was expected for three out of the four studied traits (SLA, Hrep and SRA) as they are good proxies for plant relative growth rate (Hunt \& Cornelissen 1997; McKenna \& Shipley 1999; Cornelissen et al. 2003). Regarding RTD, the negative correlation found between its CWM and biomass production was expected as this root trait is considered to be negatively correlated with plant growth rate (Hummel et al. 2007).

It is remarkable that the similarity in the relationship between CWM and production holds true for both aboveground and below-ground traits, although root traits were measured ex situ. These results are consistent with those of Wahl and Ryser (2000) and Hummel et al. (2007) who showed that, in herbaceous species, there is a close relationship between root traits and the overall functioning of the plant, approached by relative growth rate and maximum height.

\section{The $\mathrm{FD}_{\mathbf{Q}}$ - biomass production relationship}

We found a strong negative relationship between biomass production of plant assemblages and their $\mathrm{FD}_{\mathrm{Q}}$ values, which was significant at the $5 \%$ level for four out of the nine studied traits (six out of nine at the 10\% level) and at the 10\% level for multi-traits $\mathrm{FD}_{\mathrm{Q}}$. When all significant factors were tested together in a stepwise mixed model, the negative effect of $\mathrm{FD}_{\mathrm{Q}}$ was maintained for SLA and LCC whereas a minor yet significant positive effect of $\mathrm{FD}_{\mathrm{Q}}$ for Hrep and RTD was found.

Negative relationships between $\mathrm{FD}_{\mathrm{Q}}$ and primary productivity is opposite to what was expected under the "diversity hypothesis" (Tilman 1997) but was also reported by Mokany et al. (2008). We suggest that such a negative relationship is contingent upon two conditions: (i) that low-diversity assemblages are made up of productive species; and (ii) that the increase of the FD also corresponds to an increase in the range of functional strategies. 
These two conditions are met in fertile grasslands where resource levels select for productive and competitive species (Grime 2006), which dominate poorly diversified assemblages (DiTommaso \& Aarssen 1989). FD increases then depend on the occurrence of disturbances (here, grazing) or stress (here, soil salinity); the more diversified assemblages then include stress-tolerant and ruderal species (Díaz, Lavorel, McIntyre, et al. 2007) which are poorly productive compared to competitive and exploitative species dominating the low FD assemblages (Grime 2006). We suggest that the increase in FD, in such fertile habitats, results in a "dilution" effect of the assemblage's growth capacity compared to poorly diversified assemblages. This process may explain the negative relationships observed in this study between $\mathrm{FD}_{\mathrm{Q}}$ and production above the 0.4 threshold and may be generalized to other fertile habitats.

The results shown in Fig. 1 suggest that the relationship between FD and production might be negative only above a threshold value and that its general shape, over the entire range of FD investigated $\left(0.1<\mathrm{FD}_{\mathrm{Q}}<0.7\right)$, should be bellshaped. The effects of niche complementarity favorable to biomass production may indeed dominate up to $\mathrm{FD}_{\mathrm{Q}}$ values of approximately 0.4 in our study whereas, beyond this threshold, the dilution effect may dominate. We suggest that such a bell-shaped pattern between FD and biomass production may be general in fertile habitats while it remains rarely noticed because the range of FD investigated may be too small or certain parts might be under-sampled. For example, Laughlin (2011) concluded that $\mathrm{FD}_{\mathrm{Q}}$ has a positive effect on ecosystem processes by considering a $\mathrm{FD}_{\mathrm{Q}}$ range between 0 and 0.4 only. The limited number of studies recording a negative relationship between ecological processes and FD may also be due to the scarcity of both long-term experimental work and field studies. It is indeed likely that the species turnover and functional adjustments occurring in natural assemblages due to long term biotic interactions modulate the functional structure and are involved in the negative relationship between biomass production and FD in this field study, as in Schumacher and Roscher (2009). Then, the positive monotone FD-production relationships observed by Jiang et al. (2007) over a wide range of FD might depends on the short time period of growth before the productivity of experimental assemblages was measured (i.e., only 2, 4 and 6 months).

\section{A combined effect of $\mathrm{FD}_{\mathrm{Q}}$ and $\mathrm{CWM}$ on biomass production}

After a stepwise variable selection procedure, the best predictive model was found to include both $\mathrm{CWM}$ and $\mathrm{FD}_{\mathrm{Q}}$ values. This result is consistent with those of Schumacher and Roscher (2009) and Roscher et al. (2012) showing that the inclusion of community-weighted mean trait values, functional trait diversity and abiotic variables in a single model may enhance the ability to predict biomass production and other ecosystem processes in plant assemblages.

Surprisingly, $\mathrm{FD}_{\mathrm{Q}}$ (Hrep) and $\mathrm{FD}_{\mathrm{Q}}(\mathrm{RTD})$, which were found to be negatively related to biomass production when considered independently, were found to have a slight positive effect on production in the global model. Such contrasts between models investigating only functional diversity effects and more complex models were already reported by Schumacher and Roscher (2009). In our study, this result provides some support to the diversity hypothesis. However, the two other $\mathrm{FD}_{\mathrm{Q}}$ indices included in the multiple regression model (i.e., $\mathrm{FD}_{\mathrm{Q}}(\mathrm{SLA})$ and $\mathrm{FD}_{\mathrm{Q}}(\mathrm{LCC})$ ) showed a negative effect on biomass production, and the proposed "dilution" effect was thus proven to be robust.

\section{Conclusion}

In the studied wet grassland, we found both negative and positive relationships between biomass production and $\mathrm{FD}_{\mathrm{Q}}$. This result only partially supports Tilman's “diversity hypothesis" (1997) and we suggest that, above a certain $\mathrm{FD}_{\mathrm{Q}}$ threshold, a dilution effect could overcome the complementarity effect in such fertile habitats. On the other hand, the traits of dominant species appeared to be good predictors of biomass production, supporting Grime's (1998) "biomass ratio hypothesis". In forthcoming studies, the complementarity and dilution effects suggested in the relationship between ecosystem processes and functional diversity should be explored by taking into account wide ranges of FD levels and a large range of site productivity, being careful to consider communities that have been established for several years.

\section{Acknowledgments}

PC was funded by a grant from the French "Ministère de l'enseignement Supérieur et de la recherche". The authors are grateful to O. Jambon, M. Thomann, F. Clément and F. Jean for their help in the field and for the experimental root trait measurements and L. Parize, F. Nassur and T. Fontaine for their help in the set-up of the root trait experiment. We would also like to thank C. Roumet, P. Laîné, N. Montès and A. Gardarin for the discussions on the design and data analysis as well as V. Jung for helpful comments on an earlier version. The authors particularly thank the "Parc Interrégional du Marais Poitevin" and the "Mairie des Magnils-Reigniers" for allowing us to work in the commons and for technical support. S. Mullin corrected the English. We thank the managing editor, Dr. Hövemeyer, and three anonymous reviewers for their fruitful comments and suggestions which helped to improve the manuscript. This work is a contribution to GDR 2574 "TRAITS".

\section{Appendix A. Supplementary data}

Supplementary data associated with this article can be found, in the online version, at http://dx.doi.org/10.1016/ j.baae.2013.01.002. 


\section{References}

Amiaud, B., Bouzillé, J.-B., Tournade, F., \& Bonis, A. (1998). Spatial patterns of soil salinities in old embanked marshlands in western France. Wetlands, 18, 482-494.

Burnham, K. P., \& Anderson, D. R. (2002). Model selection and multimodel inference: a practical information-theoretic approach (2nd ed.). New York, USA: Springer.

Cornelissen, J. H., Lavorel, S., Garnier, E., Díaz, S., Buchmann, N., Gurvich, D. E., et al. (2003). A handbook of protocols for standardised and easy measurement of plant functional traits worldwide. Australian Journal of Botany, 51, 335-380.

Craine, J. M., Wedin, D. A., Chapin, F. S., \& Reich, P. B. (2002). Relationship between the structure of root systems and resource use for 11 North American grassland plants. Plant Ecology, 165, $85-100$.

Díaz, S., \& Cabido, M. (2001). Vive la différence: Plant functional diversity matters to ecosystem processes. Trends in Ecology \& Evolution, 16, 646-655.

Díaz, S., Hodgson, J. G., Thompson, K., Cabido, M., Cornelissen, J. H. C., Jalili, A., et al. (2004). The plant traits that drive ecosystems: Evidence from three continents. Journal of Vegetation Science, 15, 295-304.

Díaz, S., Lavorel, S., de Bello, F., Quétier, F., Grigulis, K., \& Robson, T. M. (2007). Incorporating plant functional diversity effects in ecosystem service assessments. Proceedings of the National Academy of Sciences of the United States of America, 104, 20684-20689.

Díaz, S., Lavorel, S., McIntyre, S., Falczuk, V., Casanoves, F., Milchunas, D. G., et al. (2007). Plant traits responses to grazing: A global synthesis. Global Change Biology, 13, 313-341.

DiTommaso, A., \& Aarssen, L. W. (1989). Resource manipulation in natural vegetation: A review. Vegetatio, 84, 9-29.

Dumont, B., Rossignol, N., Loucougaray, G., Carrère, P., Chadoeuf, J., Fleurance, G., et al. (2012). When does grazing generate stable vegetation patterns in temperate pastures? Agriculture, Ecosystems \& Environment, 153, 50-56.

Garnier, E., Cortez, J., Billès, G., Navas, M., Roumet, C., Debussche, M., et al. (2004). Plant functional markers capture ecosystem properties during secondary succession. Ecology, 85, 2630-2637.

Grime, J. P. (1997). Biodiversity and ecosystem function: The debate deepens. Science, 277, 1260-1261.

Grime, J. P. (1998). Benefits of plant diversity to ecosystems: Immediate, filter and founder effects. Journal of Ecology, 86, 891-899.

Grime, J. P. (2006). Trait convergence and trait divergence in herbaceous plant communities: Mechanisms and consequences. Journal of Vegetation Science, 17, 255-260.

Hector, A., Schmid, B., Beierkuhnlein, C., Caldeira, M. C., Diemer, M., Dimitrakopoulos, P. G., et al. (1999). Plant diversity and productivity experiments in European grasslands. Science, 286, 1123-1127.

Hooper, D. U. (1998). The role of complementarity and competition in ecosystem responses to variation in plant diversity. Ecology, 79, 704-719.

Hooper, D. U., Chapin, F. S., Ewel, J. J., Hector, A., Inchausti, P., Lavorel, S., et al. (2005). Effects of biodiversity on ecosystem functioning: A consensus of current knowledge. Ecological Monographs, 75, 3-35.
Hummel, I., Vile, D., Violle, C., Devaux, J., Ricci, B., Blanchard, A., et al. (2007). Relating root structure and anatomy to wholeplant functioning in 14 herbaceous Mediterranean species. New Phytologist, 173, 313-321.

Hunt, R., \& Cornelissen, J. H. C. (1997). Components of relative growth rate and their interrelations in 59 temperate plant species. New Phytologist, 135, 395-417.

Huston, M. A., Aarsen, L. W., Austin, M. P., Cade, B. S., Fridley, J. D., Garnier, E., et al. (2000). No consistent effect of plant diversity on productivity. Science, 289, 1255.

Jiang, X. L., Zhang, W. G., \& Wang, G. (2007). Effects of different components of diversity on productivity in artificial plant communities. Ecological Research, 22, 629-634.

Laughlin, D. C. (2011). Nitrification is linked to dominant leaf traits rather than functional diversity. Journal of Ecology, 99, 1091-1099.

Lavorel, S., \& Garnier, E. (2002). Predicting changes in community composition and ecosystem functioning from plant traits: Revisiting the Holy Grail. Functional Ecology, 16, $545-556$.

Lepš, J. (2004). What do the biodiversity experiments tell us about consequences of plant species loss in the real world? Basic and Applied Ecology, 5, 529-534.

Lepš, J., de Bello, F., Lavorel, S., \& Berman, S. (2006). Quantifying and interpreting functional diversity of natural communities: Practical considerations matter. Preslia, 78, 481-501.

Loreau, M. (2000). Biodiversity and ecosystem functioning: Recent theoretical advances. Oikos, 91, 3-17.

Loreau, M., Naeem, S., Inchausti, P., Bengtsson, J., Grime, J. P., Hector, A., et al. (2001). Biodiversity and ecosystem functioning: Current knowledge and future challenges. Science, 294, 804-808.

Magurran, A. E. (1988). Ecological diversity and its measurement. Princeton: Princeton University Press.

Marion, B., Bonis, A., \& Bouzillé, J.-B. (2010). How much does grazing-induced heterogeneity impact plant diversity in wet grasslands? Ecoscience, 17, 229-239.

McGill, B. J., Enquist, B. J., Weiher, E., \& Westoby, M. (2006). Rebuilding community ecology from functional traits. Trends in Ecology \& Evolution, 21, 178-185.

McKenna, M., \& Shipley, B. (1999). Interacting determinants of interspecific relative growth: Empirical patterns and a theoretical explanation. Ecoscience, 6, 286-296.

McNaughton, S. J., Milchunas, D. G., \& Frank, D. A. (1996). How can net primary productivity be measured in grazing ecosystems? Ecology, 77, 974-977.

Millenium Ecosystem Assessment. (2005). Ecosystems and human well-being: biodiversity synthesis. Washington: World Resources Institute.

Mokany, K., Ash, J., \& Roxburgh, S. (2008). Functional identity is more important than diversity in influencing ecosystem processes in a temperate native grassland. Journal of Ecology, 96, 884-893.

Mouillot, D., Villéger, S., Scherer-Lorenzen, M., \& Mason, N. W. H. (2011). Functional structure of biological communities predicts ecosystem multifunctionality. PLOS ONE, 6, e17476.

Ricotta, C., \& Moretti, M. (2011). CWM and Rao's quadratic diversity: A unified framework for functional ecology. Oecologia, 167, 181-188.

Roscher, C., Schumacher, J., Gubsch, M., Lipowsky, A., Weigelt, A., Buchmann, N., et al. (2012). Using plant functional traits 
to explain diversity-productivity relationships. PLoS ONE, 7, e36760.

Rossignol, N., Bonis, A., \& Bouzillé, J.-B. (2011a). Grazinginduced vegetation patchiness controls net $\mathrm{N}$ mineralization rate in a semi-natural grassland. Acta Oecologica, 37, 290-297.

Rossignol, N., Bonis, A., \& Bouzillé, J.-B. (2011b). Impact of selective grazing on plant production and quality through floristic contrasts and current-year defoliation in a wet grassland. Plant Ecology, 212, 1589-1600.

Roumet, C., Urcelay, C., \& Díaz, S. (2006). Suites of root traits differ between annual and perennial species growing in the field. New Phytologist, 170, 357-368.

Schenk, H. J., \& Jackson, R. B. (2002). The global biogeography of roots. Ecological Monographs, 72, 311-328.

Schulze, E.-D., \& Mooney, H. A. (1993). Biodiversity and ecosystem function. New York: Springer.

Schumacher, J., \& Roscher, C. (2009). Differential effects of functional traits on aboveground biomass in semi-natural grasslands. Oikos, 118, 1659-1668.

Tilman, D. (1997). Distinguishing between the effects of species diversity and species composition. Oikos, 80, 185.
Tilman, D., Knops, J., Wedin, D., Reich, P., Ritchie, M., \& Siemann, E. (1997). The influence of functional diversity and composition on ecosystem processes. Science, 277, 1300-1302.

Violle, C., Navas, M.-L., Vile, D., Kazakou, E., Fortunel, C., Hummel, I., et al. (2007). Let the concept of trait be functional. Oikos, $116,882-892$.

Wahl, S., \& Ryser, P. (2000). Root tissue structure is linked to ecological strategies of grasses. New Phytologist, 148, 459-471.

Wang, X., Fang, J., Sanders, N. J., White, P. S., \& Tang, Z. (2009). Relative importance of climate vs local factors in shaping the regional patterns of forest plant richness across northeast China. Ecography, 32, 133-142.

Westoby, M., Falster, D. S., Moles, A. T., Vesk, P. A., \& Wright, I. J. (2002). Plant ecological strategies: Some leading dimensions of variation between species. Annual Review of Ecology and Systematics, 33, 125-159.

Wright, I. J., Reich, P. B., Westoby, M., Ackerly, D. D., Baruch, Z., Bongers, F., et al. (2004). The world-wide leaf economics spectrum. Nature, 428, 821-827.

\section{SciVerse ScienceDirect}

